\title{
LANDSLIDE MOVEMENTS RELATED TO PRECIPITATION. ANALYSIS OF A STATISTICAL SAMPLE FROM THE GREEK AREA
}

\author{
Gournelos T. ${ }^{1}$, Nastos P. T. ${ }^{1}$, Chalkias D. ${ }^{2}$, Tsagas D. ${ }^{2}$, Theodorou D. ${ }^{1}$ \\ ${ }^{1}$ University of Athens, Faculty of Geology and Geoenvironment, Department of Geography and Climatology, \\ 15784 Athens, Greece \\ ${ }^{2}$ Harokopio University, Kallithea Athens, Greece
}

\begin{abstract}
It is known that the Greek area the majority of landslides have been triggered by heavy precipitation. This paper examines the statistical properties of precipitation directly related to the landslides in the Greek area. A database was constructed for the period 1980-1988, where for each landslide the daily maximum, the monthly and the annual precipitation totals were recorded. All these data were introduced in a GIS environment. Finally, a statistical analysis was carried out to study the relation between precipitation and landslide movement.
\end{abstract}

Key words: Landslides, precipitation, Greece

\section{Introduction}

The landslide movements are relatively intense in the Greek area and are directly related to the relief, lithology and vegetation. The principal mechanisms for triggering a landslide are the heavy precipitation events, earthquakes and human intervention. The precipitation variability and the distribution of precipitation frequency in the Mediterranean and Greece have been studied by many researchers (Repapis 1986, Nastos 1993, Metaxas et al. 1999, Maheras and Anagnostopoulou 2003, Nastos and Zerefos 2007, 2008). In Greece, 92\% of the precipitation during the wet season (October-March) is produced by cyclonic circulation types (Maheras and Anagnostopoulou 2003), while during the summer the intense precipitation and hail events are associated with the geostrophic vorticity advection (Spanos 2004). The winter is characterized by cyclonic variability and low mean pressure in the Mediterranean. The highest values of pressure appear in the east area and are associated with the Siberian anticyclone. In March and April, as the main characteristics of the upper air flow (e.g. Jet stream) start moving to the north from their southern winter positions. The rainy season continues until May, when a dry summer regime is established. The precipitation over Greece, is rarely affected by Atlantic cyclones, but is linked to cyclogenesis in the Mediterranean region (Luterbacher et al.2006). According to the results of climate models projection (A1B scenario) precipitation will shift to the north and during 2080-2099 the precipitation will decrease over 20\% with respect to the period 1980-1999 (IPCC 2007) at the southeast areas of the Mediterranean. Besides, the frequency of intense cyclones in the Mediterranean will significantly decrease, but the future cyclones will be more intense (Anagnostopoulou et al. 2006). In a more recent study, Nastos \& Zerefos (2008) showed that extreme precipitation events appear during winter months in the western and eastern sub regions of Greece, and mainly during autumn in the rest of the country. Moreover, the fitted Gamma distributions to the daily precipitation totals with respect to the 45 -year period 


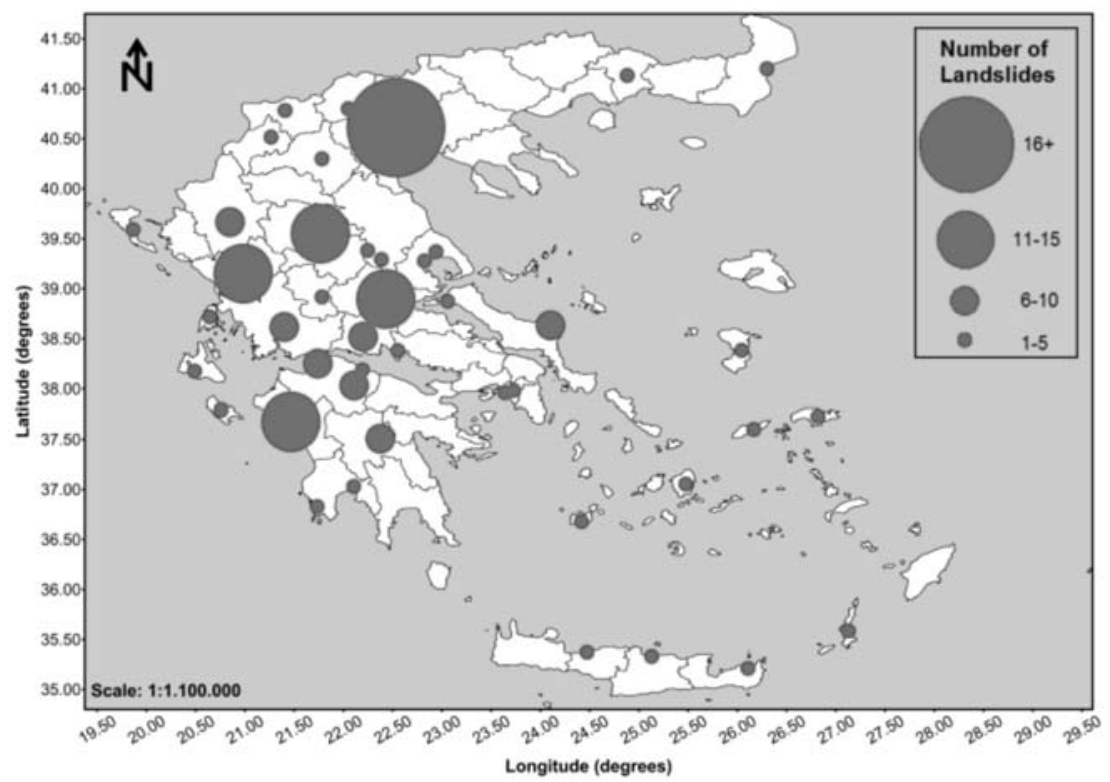

Fig. 1: Spatial distribution of the landslides in relation to the nearest sites with precipitation observations.

(1957-2001) revealed that high values of variance and scale parameter of the fitted Gamma distributions appear in the western, eastern and southeastern Greece, especially during the period 19912000 , pointing out the appearance of the extreme daily precipitation.

There are several works in the international literature related to the spatial distribution and characteristics of landslides in the Greek area (Koukis 1982, Koukis \& Ziourkas 1991, Lekkas 2001, Gournelos et al. 2006). Nevertheless, studies which focus on the relationship of landslide movements and precipitation are limited and only of local character (Anagnostopoulos \& Georgiadis 1997, Koukis et al. 1997, Nikolaou et al. 1997). In the present study, an effort is made to examine the relationship between landslide movements and precipitation in the wider Greek area.

\section{Data and Analysis}

The study of the correlation of precipitation and landslides requires the collection of many variables in spatial and temporal distribution. For this reason, firstly, a database of landslide phenomena was constructed (Gournelos et al. 2006) for the period 1970-1988 and in the process all the factors causing these phenomena were analyzed.

It is absolutely certain that the majority of landslides happen due to precipitation events. In order to examine the relationship between precipitation and landslides, a second database concerning daily maximum, monthly and annual precipitation totals was constructed. The precipitation data were derived from the Hellenic National Meteorological Service (HNMS) and concern meteorological stations, which are representative to the areas, where sustained landslides occurred. The spatial distribution of the sites (HNMS meteorological stations) with precipitation data in close distance to the area of recorded landslides is depicted in Figure 1. The proportional circles appeared in Figure 1 show only the number of landslides in the neighboring area of the meteorological stations.

Finally, after entering the data into a G.I.S. environment, and the development of various thematic maps, statistical analysis of the rainfall data was carried out. 


\section{Results and discussion}

The correlation of the precipitation and landslide events was initiated mainly by Gaine (1980) and continued later by other researchers (Keffer et al. 1987, Grozier 1999, Wilson and Wieczorek 1995, Guzzetti et al. 2004, Aleotti 2004, Glade et al. 2005. The aforementioned authors studied either empirical relationships between precipitation and landslides by constructing intensity duration curves, or physical processing models.

The statistics of the annual, monthly and maximum daily precipitation totals associated with the recorded landslides in the wider area of Greece are presented in Table 1. It is crystal clear that in most of the cases, extreme precipitation events are associated with landslides development.

In order to examine the precipitation impact on the development of landslides, the monthly precipitation recorded in the specific months when landslides happened in the wider Greek area are depicted in Figure 2. It is remarkable that, in some cases the monthly precipitation totals exceed $250 \mathrm{~mm}$, which corresponds over $30 \%$ of the annual precipitation in several areas. Figure 3 presents the monthly precipitation totals as a percentage $(\%)$ of the respective annual precipitation totals with respect to landslides dates, for different sites of Greece. Another significant parameter which is closely related to the onset of landslides is the maximum daily precipitation totals. The recorded daily maximum precipitation totals $(\mathrm{mm})$ with respect to landslides dates, for different sites of Greece, appear in Figure 4.

Extreme daily precipitation events, that in many cases exceed $30 \mathrm{~mm}$, which is a threshold of heavy precipitation events (Nastos and Zerefos 2008), seem to be typical for the development of landslides in areas that are also vulnerable to other physical factors. In this point it is worthy to point out that,

Table 1. Statistics of the precipitation totals triggering landslide movements

\begin{tabular}{|l|c|c|c|}
\hline & $\begin{array}{c}\text { Annual } \\
\text { Precipitation }(\mathrm{mm})\end{array}$ & $\begin{array}{c}\text { Monthly } \\
\text { Precipitation }(\mathrm{mm})\end{array}$ & $\begin{array}{c}\text { Maximum daily } \\
\text { precipitation (mm) }\end{array}$ \\
\hline Number of sites & 184 & 184 & 184 \\
\hline Mean & 775.2 & 111.1 & 33.5 \\
\hline Standard deviation & 261.5 & 81.3 & 23.4 \\
\hline Maximum & 1509.9 & 390.3 & 135.5 \\
\hline Skew & 2.7 & 4.5 & 7,2 \\
\hline Kurtosis & -0.1 & 0.9 & 7.5 \\
\hline
\end{tabular}

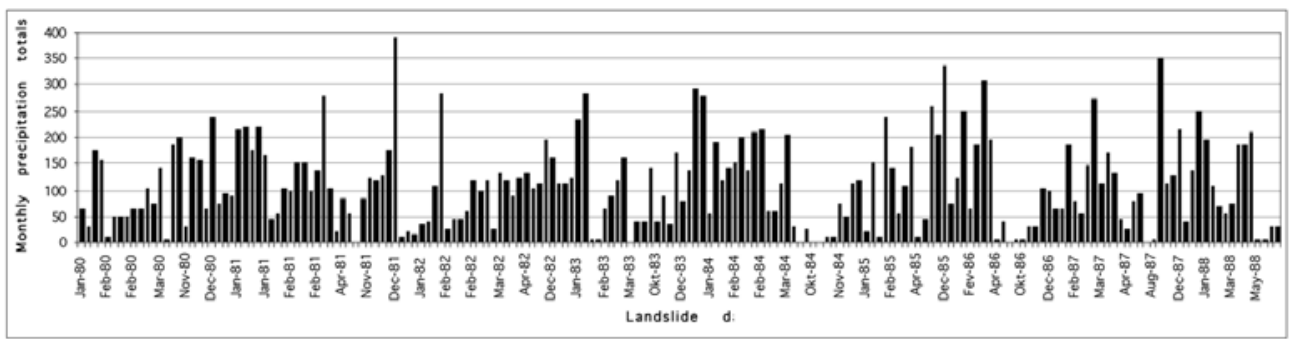

Fig. 2: Monthly precipitation totals $(\mathrm{mm})$ with respect to landslides dates, for different sites of Greece. 


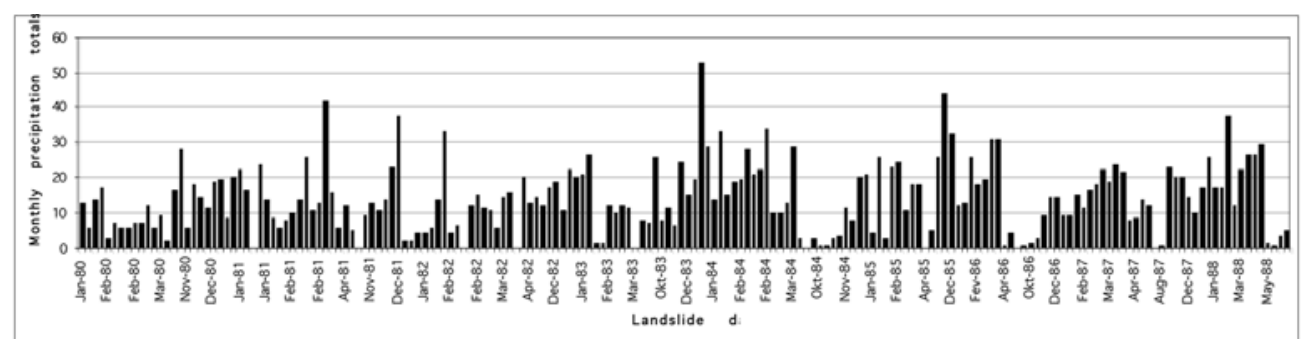

Fig. 3: Monthly precipitation totals as a percentage (\%) of the respective annual precipitation totals with respect to landslides dates, for different sites of Greece.

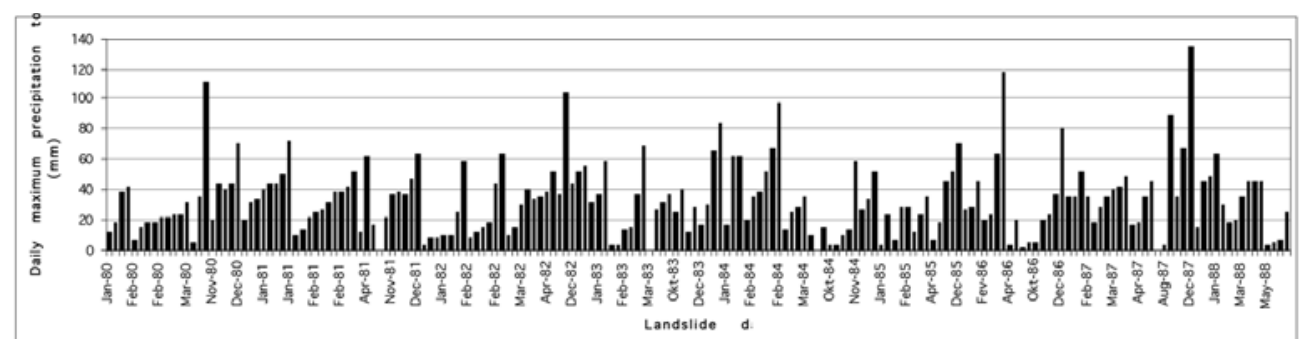

Fig. 4: Daily maximum precipitation totals $(\mathrm{mm})$ with respect to landslides dates, for different sites of Greece.

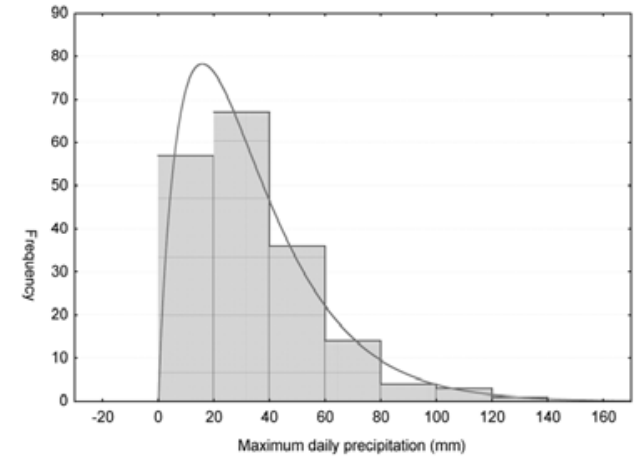

(a)

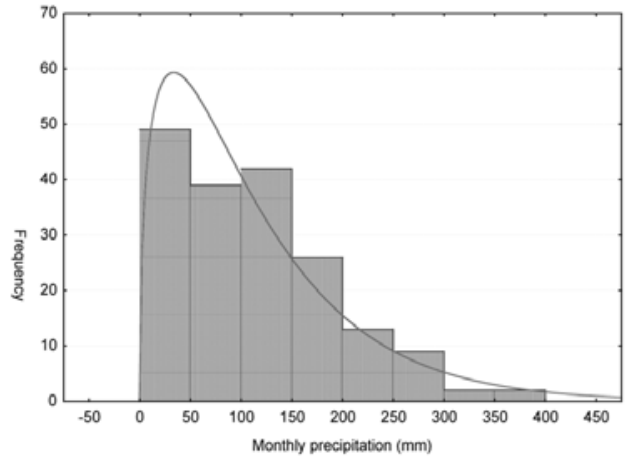

(b)

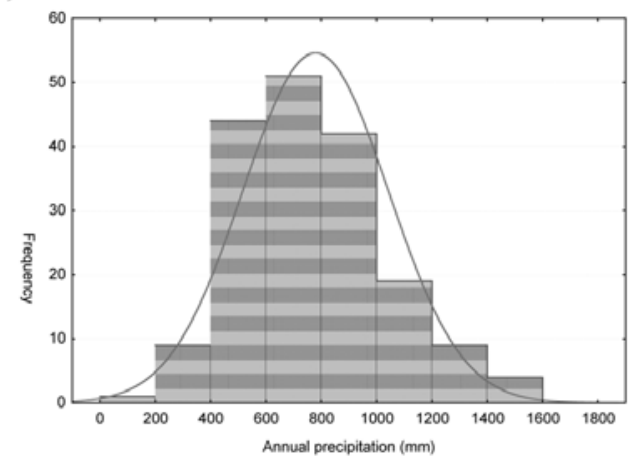

(c)

Fig. 5: Histograms of daily maximum (a), monthly (b) and annual (c) precipitation totals. 
the database used concerns landslides that occurred throughout the country, for the specific time period 1980-1988.

In the process, histogram analysis was carried out in order to find out the prevailed classes of daily maximum, monthly and annual precipitation totals corresponding to landslide movements. Besides, appropriate distributions, such as Gamma distribution for daily maximum and monthly precipitation totals and Normal distribution for the annual precipitation totals, were fitted to the histograms. Regarding daily maximum precipitation, the class $20-40 \mathrm{~mm}$ seems to be the prevailed one, while the class $0-50 \mathrm{~mm}$ and the class $600-800 \mathrm{~mm}$ correspond to the more frequent monthly and annual precipitation totals, respectively, for landslides phenomena.

\section{Conclusions}

The performed analysis, in order to show the relationship between landslide events and precipitation totals, for the whole Greek territory, during the period 1980-1988, revealed the following conclusions: The majority of the landslides were due to intense and short-term precipitation events. The mean daily maximum precipitation related to the outbreaks of landslides phenomena was found $33.5 \pm 23.4 \mathrm{~mm}$, the mean monthly precipitation $111.1 \pm 81.3 \mathrm{~mm}$, while the mean annual precipitation $775.2 \pm 261.5 \mathrm{~mm}$. The temporal distribution of landslides revealed that, their frequency, as expected, was greater within the period December-February, followed by spring and even less by summer months.

\section{References}

Aleotti, P., 2004. A warning system of rainfall - induced shallow failure. Engineering Geology 73, 247265

Anagnostopoulos, C., Georgiadis, M., 1997. Analysis of rainfall data and correlation to landslides: The case of Sykia-Pieria, Greece. Engin. Geol. and the Environment, Marinos, Koukis, Tsiambaos and Stournaras (eds), Balkema, Rotterdam.

Anagnostopoulou, Chr., Tolika, K., Flocas, H., Maheras, P., 2006. Cyclones in the Mediterranean region: Present and future climate scenarios derived from a general circulation model (HadAM3P). Advances in Geosciences 7:9-14.

Crozier, M.J., 1999. Prediction of rainfall-triggered landslides: a test of the antecedent water status model. Earth Surface Processes and Landforms 24, 825-833

Glade, T., Dikau R., Bell R., 2003. National landslide susceptibility map for Germany. Geophysical Research Abstracts Vol. 5.

Gournelos, T., Chalkias, Ch., Tsagas, D., 2006. Landslide Susceptibility Zonation of Greece Using Fuzzy Logic Rules and Geographical Information Systems. Geography 12, 114-126

Guzzetti, F., Carrarara, A., Cardinali, M., Reichenbach, P., 1999. Landslide hazard evaluation: a review of current techniques and their application in a multi-scale study, Central Italy. Geomorphology 31, 181-216.

Guzzetti, F., Cardinali, M., Reichenbach, P., Cipolla, F., Sebastiani, C., Galli, M., Salvati, P., 2004. Landslides triggered by the 23 November 2000 rainfall event in the Imperia Province, Western Liguria, Italy. Engineering Geology 73, 229-245.

IPCC, 2007. Summary for policymakers. In: S. Solomon, D. Qin, M. Manning, Z. Chen, M. Marquis, K.B. Averyt, M.Tignor and H.L. Miller, Editors, Climate Change 2007: The Physical Science Basis. Contribution of Working Group I to the Fourth Assessment Report of the Intergovernmental Panel on Climate Change, Cambridge University Press, Cambridge, United Kingdom/New York, NY, USA.

Keefer, D.K., Wilson, R. C., Mark, R.K., Brabb, E.E., Brown, W.M., Ellen, S.D., Harp, E.L., Wieczorek, G.F., Alger, C.S., Zatkin, R.S., 1987. Real-time landslide warning during heavy rainfall. Science, 
238, 921-925.

Koukis, G., Pyrgiotis, L., Rozos, D., 1997. Landslide phenomena and stability analysis related with the construction of the Ano Diakopto road deviation, Achaia country, Greece. Engin.Geol. and the Environment, Marinos, Koukis, Tsiambaos \& Stournaras (EDS) Balkema, Rotterdam.

Koukis, G., Ziourkas, C., 1991. Slope instability phenomena in Greece: a statistical analysis. Bulletin of the IAEG 43, 47-60.

Koukis, G., 1982. Mass movements in the Greek territory. A critical factor for environment evaluation and development. IV Cong. Int.Ass. Eng. Geology. Vol. III. New Delhi.

Lekkas, E., 2001. Landslide Hazards in Greece. EUG XI, European Union of Geosciences, Cambridge Publications, Abstract Volume, Vol.6, p.508, Strasbourg.

Luterbacher, J. et al., 2006. Mediterranean climate variability over the last centuries: a review. In: P. Lionello, P. Malanotte-Rizzoli and R. Boscolo (Eds), Mediterranean Climate Variability, Amsterdam. Elsevier, pp. 27-148.

Maheras, P., Anagnostopoulou, Chr., 2003. Circulation Types and their Influence on the interannual variability and precipitation changes in Greece, Mediterranean Climate-Variability and Trends. Springer Verlag, Berlin, Heidelberg, 215-239.

Metaxas, D.A., Philandras, C.M., Nastos, P.T., Repapis, C.C., 1999. Variabiility of precipitation pattern in Greece during the year. Fresenius Environmental Bulletin 8, 1-6.

Nastos, P.T., 1993. Changements de la pluviosite en region Hellenique pendant la periode 1858 - 1992. Proceedings of the $6^{\text {th }}$ Colloque International de Climatologie, 22-25 Septembre, 1993, Thessaloniki, Grece, Vol. 6, pp. 183-190.

Nastos, P.T., Zerefos, C.S., 2007. On extreme daily precipitation totals at Athens, Greece. Advances in Geosciences 10, 59-66.

Nastos, P.T., Zerefos, C.S., 2008. Decadal changes in extreme daily precipitation in Greece. Advances in Geosciences 16, 55-62.

Nikolaou, N., Koukis, G., Lambrakis, N., 1997. Rainfall and Landslide manifestation corellation in Korinthos county, Greece, in proceedings of Inrernational Symposium on Engineering Geology and the Environment, Marinos P., Koukis G., Tsiampaos G., Stournaras G. (eds.), Vol. 1, pp. 919-925.

Repapis, C.C., 1986. Temporal fluctuations of precipitation in Greece. Rivista di Meteorologia and Aeronomia XLVI, 1-2, 19-25.

Spanos, S., 2004. Climatology of cyclones during the warm-dry period in south Balkan Peninsula and eastern Mediterranean. PhD. Thesis 199 pp. (in Greek)

Wilson, R.C., Wieczorek, G.F., 1995. Rainfall thresholds for the initiation of debris flows at La Honda, California. Environmental and Engineering Geoscience 1(1), 11-27. 